\title{
Estimation of Heterosis and Combining Ability in Petunia (Petunia bybrida Hort.)
}

\author{
Hassan BAYAT ${ }^{1 *}$, Hossein NEAMATI ${ }^{1}$, Abdolreza BAGHERI $^{2}$, Ali TEHRANIFAR $^{1}$, Marjan SAIE $^{1}$ \\ ${ }^{1}$ Ferdowsi University of Mashhad, Faculty of Agriculture, Department of Horticultural Science, \\ Mashhad,Iran; hassanbayat55@gmail.com (*correspondingauthor) \\ ${ }^{2}$ Ferdowsi University of Mashhad, Faculty of Agriculture, Department of Biotechnology and Plant Breeding, Mashhad, Iran
}

\begin{abstract}
Combining ability and heterosis were estimated for ornamental and vegetative traits of four petunia (Petunia hybrida Hort.) inbred lines viz. L5 (P1), L8 (P2), L11 (P3) and L17 (P4) and their diallel hybrids in horticultural research farm of Ferdowsi University of Mashhad, Iran in 2011. The measured traits were plant height at first flower, number of leaf to first flower, flower diameter, flower tube length, internode length, stem diameter, plant height at flowering stage, plant spreading, number of branches per plant, leaf length and width. The results of combining ability for all studied traits revealed that both additive and non-additive gene effects contributed to the inheritance of the traits. Estimates of general combining ability effects showed that parent P3 was a good general combiner for most of the studied traits. For flower diameter, hybrid combination P1 $\times$ P2 had the highest significant positive specific combining ability effects. Reciprocal effects were significant for all traits and hybrid combination P1 $\times$ P2 had the highest significant positive reciprocal effects for flower tube length and plant height. Heterosis was found significant relative to both the mid parent and batter parent for all traits. For flower diameter, the highest positive values of heterotic effects were recorded in hybrid combination P $2 \times \mathrm{P} 3$ both relative to the parental mean (37.3\%) and relative to the better parent (33.9\%). It is obvious that heterotic effects represent an important resource in hybrid breeding of petunia.
\end{abstract}

Keywords: diallel cross, GCA, gene action, reciprocal effects, SCA

\section{Introduction}

Petunia (Petunia spp.), which belong to the family Solanaceae, is a popular annual bedding ornamental choice, for summer home gardens and landscaping projects, in the world (Dole and Wilkins, 2004). Petunia hybrida includes a wide variety of flower types and flower colors, and has a long-lasting bloom. As an important ornamental plant throughout spring and summer months, petunia is commercially cultivated and marketed throughout the world. Cultivars of Petunia hybrida are used in flower beds, hanging baskets, window boxes and as cut flowers. In addition, cultivars with dwarf compact plant habits and doubleflowers are used as potted plants. The contribution and information available on combining ability and heterosis studies in petunia plant is very little. Hence, there is a need to identify suitable parents with good combining ability for increasing the quality production and exploitation of hybrid vigor.

Nowadays, $\mathrm{F}_{1}$ hybrid breeding is used for many flowers; breeders and breeding companies have developed many inbred lines as candidates for parents, and have chosen the best combinations of parents of new $F_{1}$ hybrids from these lines. The information on genetics of different traits is required for devising any breeding methodology for the improvement of various traits. The selection of the breed- ing method for taking genetic problems is an equally important consideration in all genetically and breeding studies as the performance of the parents and their $\mathrm{F}_{1}$ hybrid. Diallel crossing method is most frequently used in genetic research and breeding (Bhatt et al., 2001; Kaya and Atakisi, 2004; Muraya et al., 2006; Oritz and Golmirzaie, 2004; Subhan et al., 2003), because it provides greatest information about gene effects, combining ability, heterosis, heritability and possible gene interactions (Hallauer, 2007). Combining ability describes the breeding value of parental lines to produce hybrids. Sprague and Tatum (1942) defined general combining ability (GCA) as the average performance of a line in hybrid combinations, and the specific combining ability (SCA) as those cases in which certain combinations do better or worse than expected, based on the average performance of the parents involved. Heterosis or hybrid vigor refers to the phenomenon by which an $F_{1}$ hybrid exhibits phenotypic characteristics superior to the mean of the two parents (mid parent heterosis) or to either of them (high-parent heterosis). Reciprocal effects (RE) in a diallel mating design are important in order to determine if plasmagenes from mitochondria and plastids contribute to trait inheritance (Glover et al., 2005).

Breeding of the garden petunia started in early $19^{\text {th }}$ century by the crossing of Petunia axillaris and Petunia integrifolia (Sink, 1984). The genus Petunia spp. comprises 
152

35 species mostly occurring in tropical and warm South America (Wijsman and Jong, 1985). An $\mathrm{F}_{1}$ single-flowered multiflora hybrid first became commercially available in 1949 (Weddle, 1976) and breeders have since bred dozens of $F_{1}$ hybrids. Hussein and Misiha (1978) reported that plant height, flowering time and flower size of petunia are genetically controlled by additive-dominance polygenic systems. They also observed positive and negative heterosis for these three characters. Although numerous analyses of combining ability have been reported for important agronomic traits such as yield (El-Hadi et al., 2007) and disease resistance (Mardi et al., 2004) in edible crops, few studies have investigated the combining abilities and heterosis of ornamental and vegetative characteristics in floricultural crops. The objectives of this study were to evaluate combining ability of parents and hybrids and to estimate heterosis for selecting the superior hybrids that can be used in breeding program of petunia.

\section{Materials and methods}

Plant material, diallel crosses and experimental design

Four different inbred lines of Petunia hybrida Hort. (all belonging to multiflora types) viz. L5 (P1), L8 (P2), L1 1 (P3) and L17 (P4) were used as parents in a diallel cross (Tab. 1). These inbred lines had been genetically homogeneous through inbreeding of five to six generations. The plants were grown in a greenhouse at Ferdowsi University of Mashhad ( $36^{\circ} 17^{\prime} 44^{\prime \prime} \mathrm{N}$ and $59^{\circ} 36^{\prime} 42^{\prime \prime} \mathrm{E}$ ), Iran on $9^{\text {th }}$ April 2010. A set of $4 \times 4$ diallel crosses between 4 inbred lines were crossed in all possible combinations (including reciprocals) and $12 \mathrm{~F}_{1}$ hybrids were produced. Seeds of these hybrids were sown in coco peat in plastic germination trays under greenhouse conditions on $5^{\text {th }}$ March 2011. Seedlings were transplanted in the main experimental plots at the age of 45 days. The average minimum and maximum temperatures during the crop period were $21.5^{\circ} \mathrm{C}$ and $35.7^{\circ} \mathrm{C}$ respectively. The experiment was set up in a randomized complete block design (RCBD) with three replications. The plot size was $5 \times 1 \mathrm{~m}$ and seedlings were spaced $50 \mathrm{~cm}$ on row. Each unit plot contained single row accommodating 10 plants where data were collected from randomly selected 5 plants.

Tab. 1. Characteristics of parental petunia inbred lines used to generate $12 \mathrm{~F}_{1}$ hybrids in a diallel cross design

\begin{tabular}{cccc}
\hline Inbred lines & $\begin{array}{c}\text { Flower } \\
\text { color }\end{array}$ & $\begin{array}{c}\text { No. of inbred } \\
\text { generations }\end{array}$ & $\begin{array}{c}\text { Plant height } \\
(\mathrm{cm})\end{array}$ \\
\hline L5 (P1) & purple & 5 & 36 \\
L8 (P2) & violet & 6 & 30 \\
L11 (P3) & white & 6 & 41 \\
L17 (P4) & red & 5 & 21 \\
\hline
\end{tabular}

\section{Measured traits in $F_{1}$ generation}

The measured traits in $F_{1}$ generation were number of leaf to first flower, plant height at first flower, flower diam- eter, flower tube length, internode length, stem diameter, plant height at flowering stage, plant spreading, number of branches per plant, leaf length and width.

\section{Statistical analyses}

Calculated means of all traits were used to estimate general combining ability effects of the inbred lines and specific combining ability effects of the crosses, including reciprocity effects. Analyses of combining ability were performed following Griffing's Method III and Model I of diallel analysis (Griffing, 1956) using diallel 98 software (version 2002). The GCA/SCA variance ratios with a theoretical maximum of unity were computed according to Baker (1978). This ratio was calculated to determine the relative importance of GCA and SCA effects. Mid-parent heterosis (MPH) and high-parent heterosis $(\mathrm{HPH})$ were estimated using the following formula (Hallauer and Mirinda, 1988):

$$
\begin{aligned}
& \text { Mid parent heterosis }(\mathrm{MPH})=\frac{\mathrm{F}_{1}-\text { Mid parent }}{\text { Mid parent }} \times 100 \\
& \text { Mid parent heterosis }(\mathrm{HPH})=\frac{\mathrm{F}_{1}-\text { High parent }}{\text { High parent }} \times 100
\end{aligned}
$$

\section{Results and discussion}

Combining ability analysis revealed that variances due to GCA and SCA were significant for all traits indicating that both additive and non-additive gene actions played significant role for the expression of these traits (Tab. 2). From the GCA/SCA ratio $(<1.0)$ for plant height at first flower, flower diameter and flower tube length indicates that these traits were under larger influence of non-additive genetic effects (dominance and epistasis) (Tab. 2). For other traits the magnitude of GCA variances was however higher than SCA variances which revealed preponderance of additive gene action for these traits (Tab. 2), which is in accordance with the results of Ahmad et al. (2009) in tomato, Hemanthkumar et al. (2008) in gladiolus, Hussein and Misiha (1978) in petunia and Lou et al. (2010) in zinnia. Romanus et al. (2008) and also Satija and Thukral (1985) have provided evidence for the greater importance of additive gene action in hybrid breeding outcomes. Reciprocal effects mean squares were significant and highly significant for all the measured traits, showing that inheritance of these traits governs not only nuclear but also plasma-genes (Tab. 2). The total genetic variability was partitioned into general combining ability (GCA), specific combining ability (SCA) and reciprocal effects (RE) as defined according to Griffing (1956).

\section{General combining ability effects}

The estimates of GCA effects for plant height at first flower showed that parents P3 and P4 had the highest positive $\left(2.33^{* *}\right)$ and negative $\left(-2.28^{* *}\right)$ GCA effects, 
Tab. 2. Analysis of variance for combining ability of plant height at first flower, number of leaf to first flower, flower diameter, flower tube length, internode length, stem diameter, plant height, plant spreading, number of branches per plant, leaf length and width in hybrids and their parents of petunia

\begin{tabular}{|c|c|c|c|c|c|c|c|c|c|c|c|c|}
\hline \multicolumn{13}{|c|}{ Mean sum of square } \\
\hline $\begin{array}{l}\text { Source of } \\
\text { variation }\end{array}$ & d.f. & $\begin{array}{l}\text { Plant } \\
\text { height } \\
\text { at first } \\
\text { flower } \\
(\mathrm{cm})\end{array}$ & $\begin{array}{c}\text { Number } \\
\text { of leaf } \\
\text { to first } \\
\text { flower } \\
(\mathrm{cm}) \\
\end{array}$ & $\begin{array}{c}\text { Flower } \\
\text { diameter } \\
(\mathrm{cm})\end{array}$ & $\begin{array}{l}\text { Flower } \\
\text { tube } \\
\text { length } \\
(\mathrm{cm})\end{array}$ & $\begin{array}{c}\text { Internode } \\
\text { length } \\
(\mathrm{cm})\end{array}$ & $\begin{array}{c}\text { Stem } \\
\text { diameter } \\
(\mathrm{mm})\end{array}$ & $\begin{array}{l}\text { Plant } \\
\text { height } \\
(\mathrm{cm})\end{array}$ & $\begin{array}{c}\text { Plant } \\
\text { spreading } \\
(\mathrm{cm})\end{array}$ & $\begin{array}{c}\text { Number } \\
\text { of } \\
\text { branches } \\
\text { per plant }\end{array}$ & $\begin{array}{l}\text { Leaf } \\
\text { length } \\
(\mathrm{cm})\end{array}$ & $\begin{array}{r}\text { Leaf } \\
\text { width } \\
(\mathrm{cm})\end{array}$ \\
\hline GCA & 3 & $44.71^{*}$ & $9.01^{*}$ & $0.20^{*}$ & $0.07^{\circ}$ & $1.40^{\prime \prime}$ & $0.74^{\prime \prime}$ & 303.04 & $1029^{\prime \prime}$ & $28.80^{*}$ & $2.63^{*}$ & $0.14^{\prime \prime}$ \\
\hline SCA & 2 & $148.92^{*}$ & $2.20^{\circ}$ & $6.00^{*}$ & $0.13^{*}$ & $0.18^{* \prime}$ & 0.22 & $12.10^{\circ}$ & $48.90^{\circ}$ & $1.70^{\circ}$ & $1.90^{*}$ & $0.08^{\circ}$ \\
\hline $\mathrm{RE}$ & 6 & $7.79^{*}$ & $6.90^{*}$ & $0.16^{\prime \prime}$ & 0.06 & $0.28^{* \prime}$ & $0.37^{\prime \prime}$ & $14.70^{* \prime}$ & $133.3^{*}$ & $29.50^{*}$ & $2.32^{*}$ & $0.16^{\prime \prime}$ \\
\hline Error & 22 & 0.12 & 0.55 & 0.03 & 0.02 & 0.03 & 0.02 & 2.20 & 11.10 & 0.49 & 0.04 & 0.02 \\
\hline GCA/SCA & & 0.31 & 4.02 & 0.03 & 0.53 & 7.70 & 3.40 & 25.00 & 21.00 & 16.70 & 1.40 & 1.75 \\
\hline
\end{tabular}

${ }^{*}$ Significant at $5 \%$ level of probability; ${ }^{* *}$ Significant at $1 \%$ level of probability

respectively (Tab. 3). Reduction of plant height at first flower could be obtained by using P1 and P4 as parents in petunia breeding programs, because they had negative GCA estimates that could be used for developing of dwarf compact $F_{1}$ hybrid. In case of flower diameter and flower tube length as the main goals of petunia breeding programs, parent $\mathrm{P} 2$ showed the highest positive significant GCA effects (Tab. 3). As can be seen, for internode length, stem diameter, plant height, plant spreading and number of branch per plant, parents $\mathrm{P} 3$ and $\mathrm{P} 4$ had the highest positive and negative GCA values, respectively (Tab. 3). These parents can be useful in breeding programmes for the increase and decrease of these traits. The parents P3 showed the highest significant positive GCA values for leaf length and width (Tab. 3). Thus this parent was the best general combiner to use in crosses for the improvement of leaf length and width.

\section{Specific and reciprocal combining ability effects}

Estimates of specific and reciprocal combining ability effects were presented in Tab. 4 and 5. For plant height at first flower, hybrid combination P2 $\times$ P3 had the highest significant positive SCA value (2.32 "), while P1 x P2 had the highest significant negative SCA value (Tab. 4). Reciprocity effects were outstanding in hybrid combinations $\mathrm{P} 1 \times \mathrm{P} 4$ and P1 $\times \mathrm{P} 3$ for plant height at first flower and number of leaf to first flower, respectively (Tab. 4). Hybrid combinations $\mathrm{P} 1 \times \mathrm{P} 4$ and $\mathrm{P} 2 \times \mathrm{P} 3$ showed positive significant SCA effect for number of leaf to first flower (Tab. 4).

For flower diameter, hybrid combinations $\mathrm{P} 1 \times \mathrm{P} 2$ and $\mathrm{P} 2 \times \mathrm{P} 3$ had the highest significant $(p<0.01)$ positive SCA effects indicating these combinations were the best specific combiner to increase the trait. For flower tube length hybrids $\mathrm{P} 2 \times \mathrm{P} 3$ and $\mathrm{P} 1 \times \mathrm{P} 3$ showed the highest positive $\left(0.14^{* \prime}\right)$ and negative $\left(-0.11^{* *}\right)$ significant SCA effects, respectively.

Hybrid combinations P1 × P3 $\left(0.09^{*}\right), \mathrm{P} 2 \times \mathrm{P} 3$ $\left(0.27^{\prime \prime}\right)$ and $\mathrm{P} 3 \times \mathrm{P} 4\left(0.14^{*}\right)$ showed higher significant positive SCA values for internode length (Tab. 4 ). In contrast, cross combination P2 $\times$ P 4 and P1 $\times$ P2 had highly significant and negative SCA effects for internode length (Tab. 4). Three combinations viz. P1 × P3, P1 × P4 and P2 $\times \mathrm{P} 3$ were the best specific combinations to enhance stem diameter in petunia (Tab. 4).

Hybrid combinations $\mathrm{P} 1 \times \mathrm{P} 3$ and $\mathrm{P} 2 \times \mathrm{P} 3$ were the best specific combinations to enhance plant height and plant spreading (Tab. 5). The hybrid combination P $1 \times \mathrm{P} 4$ was the best specific combiner for a potted flowering plant because of exhibiting the highest negative SCA effect for plant height (Tab. 5). Hybrid combination P1 x P2 had the highest significant and positive reciprocity effects for plant height and plant spreading (Tab. 5). In combining ability the maternal effects which came through cytoplas-

Tab. 3. Estimates of general combining ability (GCA) effects of the parents for plant height at first flower, number of leaf to first flower, flower diameter, flower tube length, internode length, stem diameter, plant height, plant spreading, number of branches per plant, leaf length and width in petunia

\begin{tabular}{|c|c|c|c|c|c|c|c|c|c|c|c|}
\hline Parents & $\begin{array}{c}\text { Plant } \\
\text { height at } \\
\text { first flower } \\
(\mathrm{cm})\end{array}$ & $\begin{array}{l}\text { Number of } \\
\text { leaf to first } \\
\text { flower } \\
(\mathrm{cm})\end{array}$ & $\begin{array}{l}\text { Flower } \\
\text { diameter } \\
(\mathrm{cm})\end{array}$ & $\begin{array}{l}\text { Flower } \\
\text { tube } \\
\text { length } \\
(\mathrm{cm})\end{array}$ & $\begin{array}{c}\text { Internode } \\
\text { length } \\
(\mathrm{cm})\end{array}$ & $\begin{array}{c}\text { Stem } \\
\text { diameter } \\
(\mathrm{mm})\end{array}$ & $\begin{array}{l}\text { Plant } \\
\text { height } \\
(\mathrm{cm})\end{array}$ & $\begin{array}{c}\text { Plant } \\
\text { spreading } \\
(\mathrm{cm})\end{array}$ & $\begin{array}{c}\text { Number of } \\
\text { branches } \\
\text { per plant }\end{array}$ & $\begin{array}{l}\text { Leaf } \\
\text { length } \\
(\mathrm{cm})\end{array}$ & $\begin{array}{l}\text { Leaf } \\
\text { width } \\
(\mathrm{cm})\end{array}$ \\
\hline P1 & $-0.58^{*}$ & $0.90^{\prime \prime}$ & $0.04^{\mathrm{ns}}$ & $-0.05^{\mathrm{ns}}$ & $0.07^{\prime \prime}$ & $0.02^{\prime \prime}$ & $2.38^{* \prime}$ & 0.33 & $0.83^{\prime \prime}$ & $-0.32^{*}$ & $-0.07^{*}$ \\
\hline P2 & $0.52^{\prime \prime}$ & $-0.30^{\circ}$ & $0.16^{\prime \prime}$ & $0.09^{*}$ & $0.08^{* \prime}$ & $0.03^{*}$ & $-0.62^{*}$ & 0.33 & $-0.99^{*}$ & $-0.17^{*}$ & $0.01^{*}$ \\
\hline P3 & $2.33^{*}$ & $0.46^{\prime \prime}$ & $-0.11^{\prime \prime}$ & $0.04^{\mathrm{ns}}$ & $0.33^{*}$ & $0.27^{*}$ & $4.71^{*}$ & $11.00^{*}$ & $1.74^{\circ}$ & $0.70^{\circ}$ & $0.15^{\circ}$ \\
\hline $\mathrm{P} 4$ & $-2.28^{* \prime}$ & $-1.07^{*}$ & $-0.09^{\circ}$ & $-0.08^{* *}$ & $-0.48^{*}$ & $-0.33^{*}$ & -6.46 & -11.67 & $-1.58^{* *}$ & $-0.20 *$ & $-0.09^{*}$ \\
\hline
\end{tabular}

${ }^{*}$ Significant at $5 \%$ level of probability; ${ }^{* *}$ Significant at $1 \%$ level of probability 
154

Tab. 4. Estimates of specific combining ability (SCA) and reciprocal (RE) effects of hybrids for plant height at first flower, number of leaf to first flower, flower diameter, flower tube length, internode length and stem diameter in petunia

\begin{tabular}{|c|c|c|c|c|c|c|c|c|c|c|c|c|}
\hline \multirow[t]{2}{*}{ Hybrids } & \multicolumn{2}{|c|}{$\begin{array}{l}\text { Plant height at } \\
\text { first flower } \\
(\mathrm{cm})\end{array}$} & \multicolumn{2}{|c|}{$\begin{array}{c}\text { Number of leaf } \\
\text { to first flower } \\
(\mathrm{cm})\end{array}$} & \multicolumn{2}{|c|}{$\begin{array}{l}\text { Flower diameter } \\
\qquad(\mathrm{cm})\end{array}$} & \multicolumn{2}{|c|}{$\begin{array}{c}\text { Flower tube } \\
\text { length } \\
(\mathrm{cm})\end{array}$} & \multicolumn{2}{|c|}{$\begin{array}{l}\text { Internode length } \\
(\mathrm{cm})\end{array}$} & \multicolumn{2}{|c|}{$\begin{array}{c}\text { Stem diameter } \\
(\mathrm{cm})\end{array}$} \\
\hline & SCA & $\mathrm{RE}$ & SCA & $\mathrm{RE}$ & SCA & $\mathrm{RE}$ & SCA & $\mathrm{RE}$ & SCA & $\mathrm{RE}$ & SCA & $\mathrm{RE}$ \\
\hline $\mathrm{P} 1 \times \mathrm{P} 2$ & $-1.05^{*}$ & $0.47^{\prime \prime}$ & 0.14 & $-0.83^{\prime \prime}$ & $0.12^{*}$ & 0.05 & 0.02 & $0.17^{*}$ & -0.04 & $0.32^{*}$ & $-0.10^{\prime \prime}$ & 0.03 \\
\hline $\mathrm{P} 1 \times \mathrm{P} 3$ & $0.25^{*}$ & -0.10 & 0.06 & $2.00^{*}$ & $-0.15^{\circ}$ & $-0.23^{* *}$ & $-0.11^{*}$ & 0.05 & $0.09^{\prime \prime}$ & $-0.35^{\prime \prime}$ & $0.07^{\prime \prime}$ & $0.33^{*}$ \\
\hline $\mathrm{P} 1 \times \mathrm{P} 4$ & $0.42^{*}$ & $1.13^{*}$ & $0.40^{*}$ & $-0.98^{\prime \prime}$ & $0.07^{\circ}$ & 0.00 & $0.05^{\circ}$ & $0.15^{*}$ & 0.00 & -0.02 & $0.05^{*}$ & -0.08 \\
\hline $\mathrm{P} 2 \times \mathrm{P} 3$ & $2.32^{*}$ & $-2.33^{*}$ & $0.51^{*}$ & $-0.68^{\circ}$ & $0.10^{*}$ & $0.27^{*}$ & $0.14^{*}$ & -0.04 & $0.27^{*}$ & $0.19^{*}$ & $0.25^{*}$ & $-0.48^{\prime \prime}$ \\
\hline $\mathrm{P} 2 \times \mathrm{P} 4$ & $-0.92^{*}$ & $0.37^{*}$ & $-0.85^{*}$ & -0.27 & $-0.11^{*}$ & 0.10 & $-0.11^{\prime \prime}$ & -0.07 & $-0.18^{\prime \prime}$ & $-0.15^{*}$ & $-0.15^{\prime \prime}$ & -0.14 \\
\hline $\mathrm{P} 3 \times \mathrm{P} 4$ & $-1.02^{*}$ & $0.83^{*}$ & $-0.27^{\prime \prime}$ & $0.82^{*}$ & $-0.02^{\mathrm{ns}}$ & $0.12^{\circ}$ & 0.00 & 0.07 & $0.14^{\circ}$ & 0.01 & -0.14 & 0.04 \\
\hline
\end{tabular}

${ }^{*}$ Significant at $5 \%$ level of probability; ${ }^{* *}$ Significant at $1 \%$ level of probability

mic effects cannot be ignored also and the $\mathrm{F}_{1}$ hybrids having desirable reciprocal effects should also be kept under consideration during future breeding. In case of number of branches per plant, two hybrids $(\mathrm{P} 1 \times \mathrm{P} 3$ and $\mathrm{P} 2 \times$ P3) had significant positive SCA effects (Tab. 5). For leaf length and width, hybrid combination $\mathrm{P} 2 \times \mathrm{P} 3$ had the highest significant positive SCA effects (Tab. 5).
Heterosis relative to mid (MPH) and high (HPH) parents

Heterosis estimates of hybrids in relation to high and mid parent are presented in Tab. 6 and 7. The hybrid combination P3 $\times$ P2 had the highest MPH (68.4\%) and $\mathrm{HPH}$ (39.5\%) for plant height at first flower, while highly negative heterosis values (MPH and $\mathrm{HPH}$ ) were observed in hybrid combinations $\mathrm{P} 1 \times \mathrm{P} 2, \mathrm{P} 2 \times \mathrm{P} 1, \mathrm{P} 4 \times \mathrm{P} 1, \mathrm{P} 4 \times \mathrm{P} 2$

Tab. 5. Estimates of specific combining ability (SCA) and reciprocal (RE) effects of hybrids for plant height, plant spreading, number of branches per plant, leaf length and width in petunia

\begin{tabular}{|c|c|c|c|c|c|c|c|c|c|c|}
\hline \multirow[t]{2}{*}{ Hybrids } & \multicolumn{2}{|c|}{$\begin{array}{l}\text { Plant height } \\
(\mathrm{cm})\end{array}$} & \multicolumn{2}{|c|}{$\begin{array}{l}\text { Plant spreading } \\
(\mathrm{cm})\end{array}$} & \multicolumn{2}{|c|}{$\begin{array}{c}\text { Number of branches } \\
\text { per plant }\end{array}$} & \multicolumn{2}{|c|}{$\begin{array}{l}\text { Leaf length } \\
(\mathrm{cm})\end{array}$} & \multicolumn{2}{|c|}{$\begin{array}{l}\text { Leaf width } \\
(\mathrm{cm})\end{array}$} \\
\hline & SCA & $\mathrm{RE}$ & SCA & $\mathrm{RE}$ & SCA & RE & SCA & $\mathrm{RE}$ & SCA & $\mathrm{RE}$ \\
\hline $\mathrm{P} 1 \times \mathrm{P} 2$ & 0.37 & $2.23^{\prime \prime}$ & $2.39^{\circ}$ & $6.33^{\prime \prime}$ & $-0.49^{\prime \prime}$ & $0.88^{*}$ & -0.24 & $0.18^{\circ}$ & $-0.04 "$ & $0.17^{\prime \prime}$ \\
\hline $\mathrm{P} 1 \times \mathrm{P} 3$ & $3.22^{*}$ & $-1.83^{\prime \prime}$ & 1.94 & 0.00 & $1.11^{*}$ & $3.90^{\circ}$ & $-0.23^{\prime \prime}$ & 0.07 & -0.02 & $0.22^{*}$ \\
\hline $\mathrm{P} 1 \times \mathrm{P} 4$ & $-2.01^{*}$ & $-1.17^{\circ}$ & $-4.11^{*}$ & -1.83 & -0.06 & 0.05 & -0.25 & $-0.35^{\prime \prime}$ & $0.01^{*}$ & 0.05 \\
\hline $\mathrm{P} 2 \times \mathrm{P} 3$ & $0.72^{*}$ & -0.33 & $3.44^{" \prime}$ & $-8.83^{*}$ & $0.44^{\circ}$ & $-2.68^{* \prime}$ & $0.60^{*}$ & $-1.47^{*}$ & 0.12 & $-0.27^{*}$ \\
\hline $\mathrm{P} 2 \times \mathrm{P} 4$ & $-1.51^{*}$ & $1.00^{\circ}$ & $-5.61^{*}$ & $-2.33^{*}$ & $-0.61^{*}$ & -0.48 & $-0.48^{\prime \prime}$ & -0.08 & $-0.07^{\prime \prime}$ & $-0.08^{\circ}$ \\
\hline $\mathrm{P} 3 \times \mathrm{P} 4$ & $-0.79^{*}$ & -0.40 & 1.94 & $2.33^{\circ}$ & $-0.38^{\prime \prime}$ & $2.47^{\prime \prime}$ & $0.09^{\prime \prime}$ & 0.00 & 0.00 & $0.08^{\circ}$ \\
\hline
\end{tabular}

${ }^{*}$ Significant at $5 \%$ level of probability; ${ }^{* *}$ Significant at $1 \%$ level of probability

Tab. 6. Estimates of heterosis relative to mid (MPH) and high parents (HPH) for 6 plant and flower traits in petunia

\begin{tabular}{|c|c|c|c|c|c|c|c|c|c|c|c|c|}
\hline \multirow[t]{2}{*}{ Hybrids } & \multicolumn{2}{|c|}{$\begin{array}{l}\text { Plant height at } \\
\text { first flower } \\
(\mathrm{cm})\end{array}$} & \multicolumn{2}{|c|}{$\begin{array}{l}\text { Number of leaf } \\
\text { to first flower } \\
(\mathrm{cm})\end{array}$} & \multicolumn{2}{|c|}{$\begin{array}{l}\text { Flower diameter } \\
\qquad(\mathrm{cm})\end{array}$} & \multicolumn{2}{|c|}{$\begin{array}{c}\text { Flower tube } \\
\text { length } \\
(\mathrm{cm})\end{array}$} & \multicolumn{2}{|c|}{$\begin{array}{l}\text { Internode length } \\
\qquad(\mathrm{cm})\end{array}$} & \multicolumn{2}{|c|}{$\begin{array}{l}\text { Stem diameter } \\
(\mathrm{cm})\end{array}$} \\
\hline & $\mathrm{MPH}$ & $\mathrm{HPH}$ & $\mathrm{MPH}$ & $\mathrm{HPH}$ & $\mathrm{MPH}$ & $\mathrm{HPH}$ & $\mathrm{MPH}$ & $\mathrm{HPH}$ & $\mathrm{MPH}$ & $\mathrm{HPH}$ & $\mathrm{MPH}$ & $\mathrm{HPH}$ \\
\hline $\mathrm{P} 1 \times \mathrm{P} 2$ & $-3.5^{\circ}$ & $-14.4^{*}$ & 0.5 & 0.5 & $35.8^{*}$ & $32.1^{*}$ & $7.9^{*}$ & $6.7^{* \prime}$ & $25.3^{\prime \prime}$ & $20.5^{\circ}$ & 7.8 & 0.0 \\
\hline $\mathrm{P} 1 \times \mathrm{P} 3$ & $15.1^{\prime \prime}$ & $6.4^{\prime \prime}$ & $32.4^{\prime \prime}$ & $27.0^{*}$ & $25.2^{*}$ & $24.8^{*}$ & $3.9^{\mathrm{ns}}$ & -0.4 & $32.8^{*}$ & $15.3^{*}$ & $14.2^{*}$ & $11.2^{\prime \prime}$ \\
\hline $\mathrm{P} 1 \times \mathrm{P} 4$ & $28.5^{\circ}$ & $-8.9^{* \prime}$ & $7.5^{\circ}$ & $-2.7^{\circ}$ & $31.3^{*}$ & $28.0^{*}$ & $13.7^{*}$ & $4.9^{\circ}$ & $27.6^{*}$ & 2.8 & $8.9^{\circ}$ & -5.5 \\
\hline $\mathrm{P} 2 \times \mathrm{P} 3$ & $40.4^{\prime \prime}$ & $16.3^{\prime \prime}$ & $6.8^{\prime \prime}$ & 2.4 & $37.3^{\prime \prime}$ & $33.9^{* \prime}$ & $12.3^{*}$ & $8.7^{*}$ & $43.1^{*}$ & $20.1^{*}$ & 4.8 & -5.2 \\
\hline $\mathrm{P} 2 \times \mathrm{P} 4$ & $5.7^{\prime \prime}$ & $-18.2^{*}$ & -4.5 & $-13.5^{*}$ & $27.7^{*}$ & $28.0^{*}$ & $6.3^{\circ}$ & -0.9 & 6.6 & $-16.7^{*}$ & $10.9^{\circ}$ & 3.2 \\
\hline $\mathrm{P} 3 \times \mathrm{P} 4$ & $19.3^{*}$ & $-19.2^{*}$ & $20.3^{* \prime}$ & $13.2^{*}$ & $29.6^{\circ}$ & $26.8^{*}$ & $16.2^{*}$ & $11.7^{*}$ & $56.7^{\circ}$ & $43.4^{*}$ & $8.3^{\circ}$ & $-8.0^{\circ}$ \\
\hline $\mathrm{P} 2 \times \mathrm{P} 1$ & $-25.1^{*}$ & -33.6 & $14.1^{\prime \prime}$ & $14.1^{*}$ & $34.0^{\prime \prime}$ & $30.3^{*}$ & -0.2 & -1.3 & 3.0 & -3.8 & 5.9 & -1.8 \\
\hline $\mathrm{P} 3 \times \mathrm{P} 1$ & $18.9^{*}$ & $9.9^{\circ *}$ & -1.4 & $-5.4^{\prime \prime}$ & $34.2^{*}$ & $33.8^{*}$ & 1.2 & -3.1 & $66.4^{*}$ & $44.4^{*}$ & -3.5 & -6.0 \\
\hline $\mathrm{P} 3 \times \mathrm{P} 2$ & $68.4^{*}$ & $39.5^{\prime \prime}$ & $18.3^{\prime \prime}$ & $13.5^{\circ}$ & $27.3^{*}$ & $24.2^{*}$ & $14.6^{\circ}$ & $10.9^{*}$ & $60.3^{*}$ & 34.6 & $32.4^{*}$ & $19.8^{\prime \prime}$ \\
\hline $\mathrm{P} 4 \times \mathrm{P} 1$ & $-37.2^{*}$ & $-55.5^{*}$ & $25.1^{\prime \prime}$ & $13.2^{*}$ & $31.3^{\prime \prime}$ & $28.0^{*}$ & 4.1 & $-4.0^{\circ}$ & $29.3^{*}$ & 4.2 & $13.6^{\circ}$ & -1.4 \\
\hline $\mathrm{P} 4 \times \mathrm{P} 2$ & $-19.5^{*}$ & $-38.1^{*}$ & 0.3 & $-9.2^{*}$ & $24.0^{*}$ & $23.6^{*}$ & $10.2^{*}$ & 2.7 & $21.3^{* \prime}$ & -5.1 & $20.5^{\prime \prime}$ & $12.1^{\prime \prime}$ \\
\hline $\mathrm{P} 4 \times \mathrm{P} 3$ & $-23.5^{*}$ & $-48.1^{*}$ & $5.0^{\circ}$ & -1.2 & $25.0^{*}$ & $22.4^{*}$ & $12.1^{*}$ & $7.8^{*}$ & $55.5^{\circ}$ & $42.3^{*}$ & 6.1 & $-9.9^{*}$ \\
\hline
\end{tabular}

${ }^{*}$ Significant at $5 \%$ level of probability; ${ }^{* *}$ Significant at $1 \%$ level of probability 


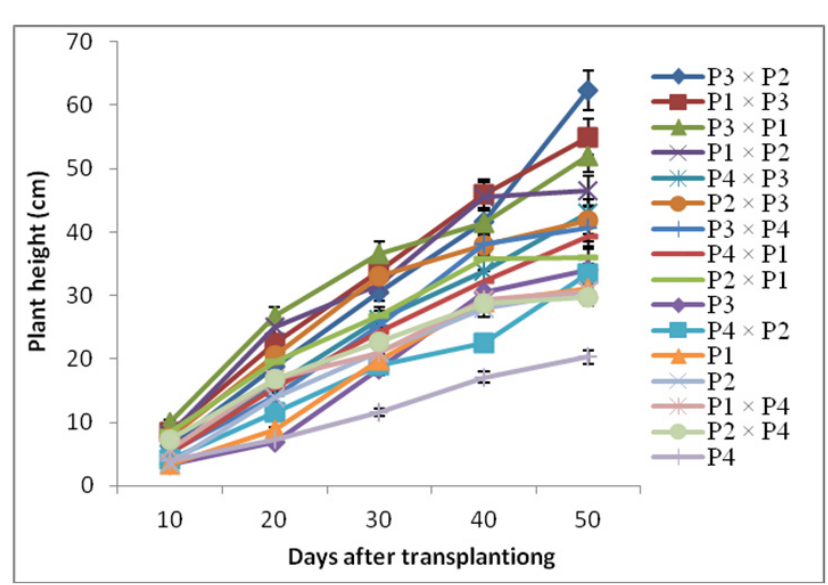

Fig. 1. The trend of increasing in plant height of parents and their 12 hybrids of petunia generated using a diallel cross design

and P4 $\times$ P3 that could be used for development of dwarf compact hybrids (Tab. 6). Heterosis values for number of leaf to first flower ranged relative to the parental mean $(-4.5$ to $32.4 \%)$ and relative to the high parent (-13.5 to $27.0 \%)$. For this trait high positive heterotic effect $(\mathrm{MPH}=32.4 \%$. $\mathrm{HPH}=27.0 \%$ ) was found in the hybrid combination P1 $\times$ P3, while hybrid combination P2 $\times$ P 4 had the highest negative significant heterosis estimates ( $\mathrm{MPH}=-4.5 \%$. $\mathrm{HPH}=-13.5 \%$ ) (Tab. 6).

For flower diameter highly significant positive heterotic effects were observed in all of the hybrid combinations and the highest positive values of heterosis were recorded in hybrid P2 $\times$ P3 $(\mathrm{MPH}=37.3 \%$. HPH =33.9\%) (Tab.

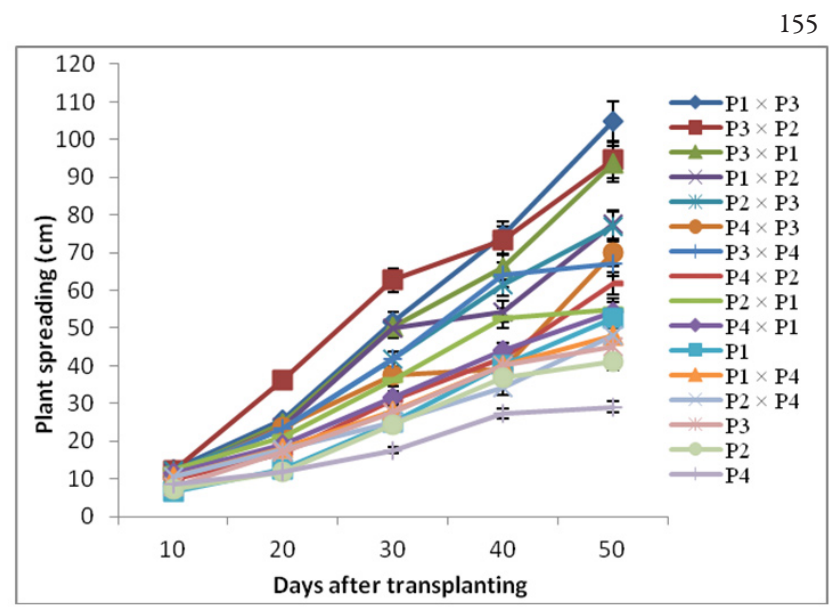

Fig. 2. The trend of increasing in plant spreading of parents and their 12 hybrids of petunia generated using a diallel cross design

6). Similar results were obtained by Hussein and Misiha (1978) in petunia and Lou et al. (2010) in zinnia. In case of flower tube length, hybrid P3 $\times$ P 4 had the highest positive significant heterotic effects relative to the parental mean (16.2\%) and high parent (11.7\%) (Tab. 6).

Highly significant positive heterotic effects for internode length relative to parental mean were recorded in 10 hybrid combinations ranged from 3.0 to $66.4 \%$. For this trait hybrid combinations $\mathrm{P} 3 \times \mathrm{P} 1$ and $\mathrm{P} 2 \times \mathrm{P} 4$ had the highest positive $(44.4 \%)$ and negative $(-16.7 \%)$ heterosis values (HPH), respectively (Tab. 6). Heterosis estimates (MPH) for stem diameter were highly positive significant in all of the hybrid combinations except for $\mathrm{P} 3 \times \mathrm{P} 1$. Het-

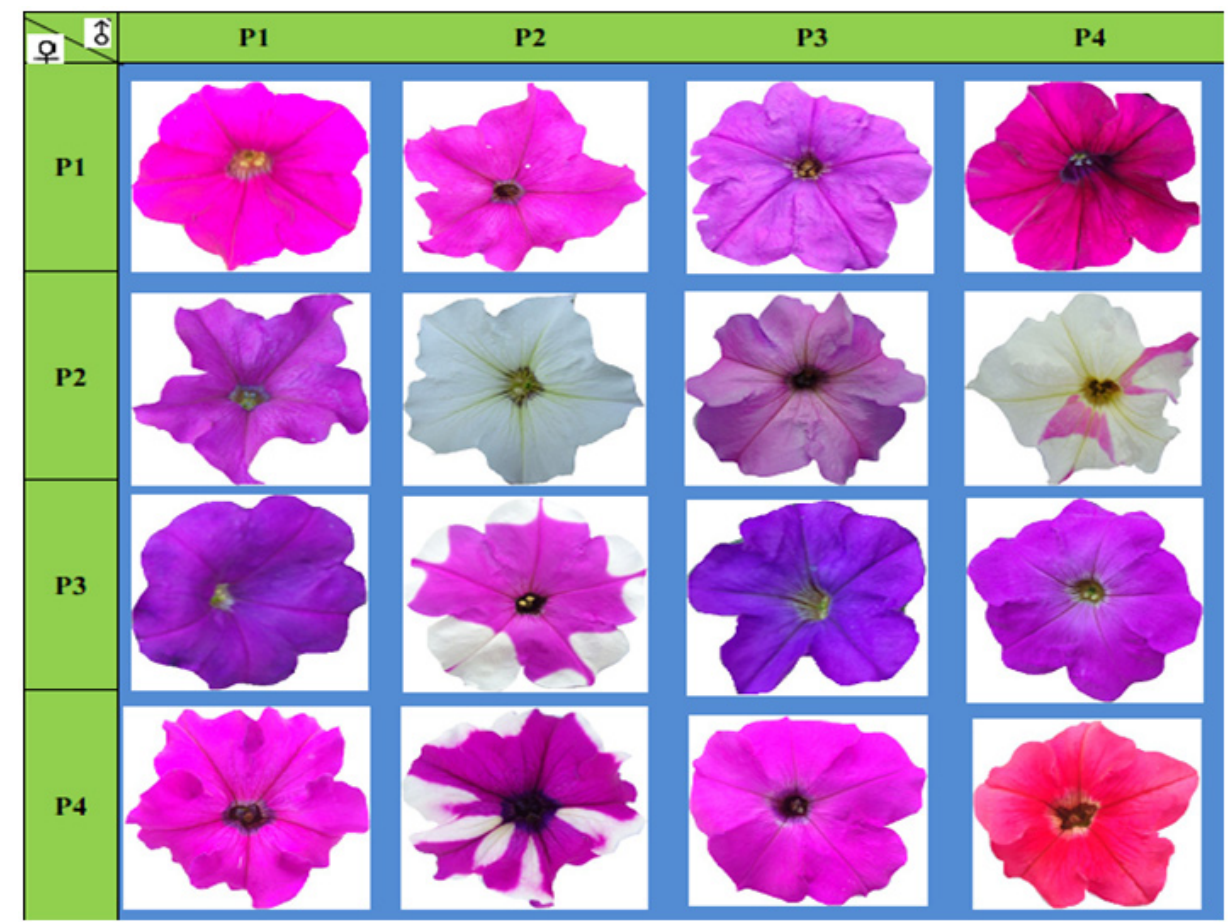

Fig. 3. Flowers of the four parents (diagonal), 6 hybrids (upper of diagonal) and 6 reciprocal hybrids (lower of diagonal) of petunia. The letters P1 to P4 indicate the four parental lines of the diallel cross 
Tab. 7. Estimates of heterosis relative to $\mathrm{mid}(\mathrm{MPH})$ and high parents $(\mathrm{HPH})$ for 5 plant characteristics in petunia

\begin{tabular}{|c|c|c|c|c|c|c|c|c|c|c|}
\hline \multirow[t]{2}{*}{ Crosses } & \multicolumn{2}{|c|}{$\begin{array}{l}\text { Plant height } \\
(\mathrm{cm})\end{array}$} & \multicolumn{2}{|c|}{$\begin{array}{c}\text { Plant spreading } \\
(\mathrm{cm})\end{array}$} & \multicolumn{2}{|c|}{$\begin{array}{c}\text { Number of branches } \\
\text { per plant }\end{array}$} & \multicolumn{2}{|c|}{$\begin{array}{l}\text { Leaf length } \\
(\mathrm{cm})\end{array}$} & \multicolumn{2}{|c|}{$\begin{array}{l}\text { Leaf width } \\
(\mathrm{cm})\end{array}$} \\
\hline & $\mathrm{MPH}$ & $\mathrm{HPH}$ & $\mathrm{MPH}$ & $\mathrm{HPH}$ & $\mathrm{MPH}$ & $\mathrm{HPH}$ & $\mathrm{MPH}$ & $\mathrm{HPH}$ & $\mathrm{MPH}$ & $\mathrm{HPH}$ \\
\hline $\mathrm{P} 1 \times \mathrm{P} 2$ & $60.7^{\prime \prime}$ & $42.4^{*}$ & $92.4 "$ & $77.6^{*}$ & $73.0^{\prime \prime}$ & $28.3^{*}$ & 2.9 & -11.4 & $10.7^{* *}$ & $6.0^{\circ}$ \\
\hline $\mathrm{P} 1 \times \mathrm{P} 3$ & $75.7^{*}$ & $57.8^{\prime \prime}$ & $78.8^{\prime \prime}$ & $78.8^{\prime \prime}$ & $97.4^{*}$ & 77.4 & 0.0 & -2.5 & $10.7^{*}$ & $12.0^{*}$ \\
\hline $\mathrm{P} 1 \times \mathrm{P} 4$ & $62.5^{*}$ & $27.5^{*}$ & $16.9^{\circ}$ & -2.4 & $18.3^{\prime \prime}$ & 16.6 & 4.9 & $-12.7^{*}$ & $17.5^{\circ}$ & 1.2 \\
\hline $\mathrm{P} 2 \times \mathrm{P} 3$ & $41.5^{\circ}$ & $39.4^{\prime \prime}$ & $65.6^{\circ}$ & $52.9^{*}$ & $13.5^{\circ}$ & $-21.4^{*}$ & 3.0 & $-9.3^{\circ}$ & 4.3 & 1.2 \\
\hline $\mathrm{P} 2 \times \mathrm{P} 4$ & $41.1^{*}$ & 1.5 & $19.4^{*}$ & 6.9 & $14.1^{*}$ & -14.6 & $16.0^{\prime \prime}$ & $11.4^{*}$ & $16.2^{* *}$ & 3.9 \\
\hline $\mathrm{P} 3 \times \mathrm{P} 4$ & $62.5^{\circ}$ & $18.1^{\circ}$ & $90.1^{\prime \prime}$ & $58.8^{* \prime}$ & $40.4^{*}$ & $24.5^{\circ}$ & $28.6^{\circ}$ & $9.3^{\circ}$ & $22.8^{* *}$ & 4.7 \\
\hline $\mathrm{P} 2 \times \mathrm{P} 1$ & $37.8^{*}$ & $22.1^{\circ}$ & $43.9^{\circ}$ & $32.9^{*}$ & $38.2^{*}$ & 2.4 & -5.1 & $-18.4^{*}$ & -1.9 & $-6.0^{\circ}$ \\
\hline $\mathrm{P} 3 \times \mathrm{P} 1$ & $94.8^{*}$ & $75.0^{*}$ & $78.8^{* \prime}$ & $78.8^{\prime \prime}$ & -3.9 & -13.6 & -2.6 & -5.1 & -4.8 & -3.6 \\
\hline $\mathrm{P} 3 \times \mathrm{P} 2$ & $44.6^{\circ}$ & $42.4^{\prime \prime}$ & $133.1^{*}$ & $115.3^{*}$ & $103.9^{* \prime}$ & $41.2^{*}$ & $69.7^{*}$ & $49.3^{* *}$ & $24.2^{* *}$ & $17.6^{\prime \prime}$ \\
\hline $\mathrm{P} 4 \times \mathrm{P} 1$ & $80.0^{*}$ & $41.2^{\prime \prime}$ & $32.4^{\prime \prime}$ & 10.6 & $16.8^{\prime \prime}$ & $15.1^{*}$ & $20.9^{* *}$ & 0.6 & $13.3^{* *}$ & -2.4 \\
\hline $\mathrm{P} 4 \times \mathrm{P} 2$ & $28.4^{*}$ & -7.6 & $41.1^{*}$ & 7.1 & 33.6 & 0.0 & $20.5^{*}$ & $15.8^{* *}$ & $23.5^{\circ}$ & $10.5^{*}$ \\
\hline $\mathrm{P} 4 \times \mathrm{P} 3$ & $67.7^{*}$ & $21.9^{* \prime}$ & 70.4 & 42.4 & -24.6 & $-33.1^{*}$ & 28.6 & $9.3^{\circ}$ & $15.9^{* *}$ & -1.2 \\
\hline
\end{tabular}

* Significant at $5 \%$ level of probability; ${ }^{* *}$ Significant at $1 \%$ level of probability

erosis values relative to high parent ranged from -8.0 to $19.8 \%$ (Tab. 6). Raghava (1984) observed highest heterosis over mid and better parent was exploited in the China aster hybrid Crego Giant Pink × AST-16.

Highly significant positive heterotic effects for plant height and plant spreading relative to parental mean were manifested in all of the hybrid combinations. The highest positive values of heterosis were recorded in $\mathrm{P} 3 \times \mathrm{P} 1$ $(\mathrm{MPH}=94.8 \% . \mathrm{HPH}=75.0 \%)$ for plant height and $\mathrm{P} 3 \times$ P2 for plant spreding $(\mathrm{MPH}=133.1 \% . \mathrm{HPH}=115.3 \%)$, respectively (Tab. 7). These results are in agreement with those of Hussein and Misiha (1987) in petunia, Premalakshmi et al. (2006) in tomato and Butorac et al. (2001) in burley tobacco (Nicotiana tabacum L.). Moreover, the trend of increasing in plant height and plant spreading for parents and their hybrid combinations were shown in Fig. 1 and 2. Fifty days after transplanting, the highest plant height was recorded in hybrid combinations $\mathrm{P} 3 \times$ P2 $(62.4 \mathrm{~cm})$ followed by P1 $\times$ P3 $(55 \mathrm{~cm})$ and P3 $\times$ P 1 $(52 \mathrm{~cm})$. In contrast, the lowest plant height was recorded in parent $\mathrm{P} 4(20.3 \mathrm{~cm})$ followed by hybrid combinations P2 $\times$ P $4(29.8 \mathrm{~cm})$ and P1 $\times$ P $4(30.4 \mathrm{~cm})$ (Fig. 1). These hybrids displayed dwarf compact habits which is the standard breeding goal for potted plants. With plant spreading, the highest and lowest values were observed in hybrid combination P1 × P3 $(105 \mathrm{~cm})$ and parent P4 $(29 \mathrm{~cm})$, respectively (Fig. 2).

Heterosis estimates (MPH) for number of branches per plant were highly positive significant in all of the hybrid combinations except for P $3 \times \mathrm{P} 1$ and $\mathrm{P} 4 \times \mathrm{P} 3$. Heterosis values for number of branches per plant ranged both relative to the parental mean (-24.6 to $103.9 \%)$ and relative to the high parent (-33.1 to $77.4 \%)$ (Tab. 7). Similar results were reported by Singh and Misra (2010) in marigold and Tiwari and Lal (2004) in tomato. The hybrid combination P3 $\times$ P2 had the highest positive and highly significant heterosis values for leaf length $(\mathrm{MPH}=69.7 \%$. HPH
$=49.3 \%)$ and leaf width $(\mathrm{MPH}=24.2 \% . \mathrm{HPH}=17.6 \%)$ (Tab. 7).

Flowers of the four parents (on the diagonal) and of the progeny of diallel crosses were presented in Fig. 3.

\section{Conclusions}

The variances for general combining ability and specific combining ability were significant and highly significant for all studied traits which indicate the presence of additive as well as non-additive gene effects. The relative magnitude of these variances indicated that additive gene effects were more prominent for all the characters except for plant height at first flower, flower diameter and flower tube length. Estimates of GCA effects showed that parent $\mathrm{P} 3$ was the best general combiner for all traits except for flower diameter that parent P2 was the best. Results of SCA showed hybrid combination P2 $\times$ P 3 had the highest SCA effects for plant height at first flower, number of leaf to first flower, internode length, stem diameter, plant spreding, leaf length and width. Reciprocal effects were also significant in all measured traits revealed that plasmagenes from mitochondria and plastids contribute to the trait inheritance. Heterosis values for all traits were highly significant relative to both the parental mean and the high parent and it is apparent that heterosis effects represent an important resource in hybrid breeding of $\mathrm{Pe}$ tunia bybrida.

\section{References}

Ahmad S, Quamruzzaman AKM, Nazim Uddin M (2009). Combining ability estimates of tomato (Solanum lycopersicum) in late summer. SAARC J Agri 7:43-56.

Baker RJ (1978). Issues in diallel analysis. Crop Sci 18 (4):533536.

Bhatt PR, Biswas VR, Kumar N (2001). Heterosis, combining ability and genetics for vitamin $\mathrm{C}$, total soluble solids and 
yield in tomato (Lycopersicon esculentum) at $1700 \mathrm{~m}$ altitude. J Agric Sci Cambridge 137:71-75.

Butorac J, Jure B, Drasko B, Zvonko M (2000). Combining abilities of agronomic and morphological traits in burley tobacco. Agric Conspec Sci 65:153-159.

Dole JM, Wilkins HF (2004). Floriculture: Principles and Species. Prentice Hall, Upper Saddle River, New Jersey.

El-Hady MM, Rizk AM, Omran MM, Regheb SB (2007). Genetic behaviour of some faba bean (Vicia faba L.) genotypes and its crosses. Ann Agric Moshtohor 45:49-60.

Glover MA, Wilmot DB, Darrah LL, Hibbard BE, Zhu X (2005). Diallel analyses of agronomic traits using chinese and U.S. maize germplasm. Crop Sci 45:1096-1102.

Griffing B (1956). Concept of general and specific combining ability in relative to diallel systems. Aust J Biol Sci 9:463493.

Hallauer AR (2007). History, contribution and future of quantitative genetics in plant breeding. Crop Sci 47:4-19.

Hallauer AR, Miranda JB (1988). Quantitative Genetics in Maize Breeding. Iowa State Univ Press, Ames, 468 p.

Hemanthkumar P, Kulkarni BS, Jagaeesha RC, Reddy BS, Shirol AM, Mulge R (2008). Combining ability and heterosis for growth characters in gladiolus (Gladiolus hybrida. Hort). Karnataka J Agric Sci 21:544-547

Hussein HAS, Misiha A (1978). Diallel analysis for some quantitative characters in Petunia hybrida Hort. Theor Appl Genet 54:17-25.

Kaya Y, Atakisi IK (2004). Combining ability analysis of some yield characters of sunflower (Helianthus annuus L.). Helia 27(41):75-84.

Lou XY, Shi Hu Q, Bao M, Mei Ye Y (2010). Analysis of combining ability of two-types of male sterile and four restorer lines of Zinnia elegans. Euphytica 174:91-103.

Mardi M, Buerstmayr H, Ghaeyazie B, Lemmens M, Moshrefzadeh N, Ruckenbauer P (2004). Combining ability analysis of resistance to head blight caused by Fusarium graminearum in spring wheat. Euphytica 139:45-50.

Muraya MM, Ndirangu CM, Omolo EO (2006). Heterosis and combining ability in diallel crosses involving maize (Zea mays) S1 lines. Aust J Exp Agric 46:387-394.
Ortiz R, Golmirzaie AM (2004). Combining ability analysis and correlation between breeding values in true potato seed. Plant Breed 123:564-567.

Premalakshmi V, Thyagaraj T, Veeraragavathatham D, Arumugam $T$ (2006). Heterosis and combining ability analysis in tomato (Lycopersicon esculentum Mill.) for yield and yield contributing traits. Vegetable Sci 33:120-122.

Raghava SPS (1984). Genetical studies in China aster (Callistephus chinemis L.). Univ. Agric. Sci., Bangalore, India, $\mathrm{PhD}$ Diss. 178 p.

Romanus KG, Hussein S, Mashela WP (2008). Combining ability analysis and association of yield and yield components among selected cowpea lines. Euphytica 162:205-210.

Satija DR, Thukral SK (1985). Genetic analysis of phytic acid content in pearl millet. Theor Appl Genet 70:693-696.

Singh D, Misra KK (2010). Diallel analysis for combining ability in marigold (Tagetes spp.) Karnataka J Agric Sci 23(2):298301.

Sink KC (1984). Origin of the cultivated P. hybrida Vilm., 7-9 p. In: Sink KC (Eds.). Petunia. Springer-Verlag.

Sprague GF, Tatum LA (1942). General vs. specific combining ability in single crosses of corn. J Amer Soc Agron 34:923932.

Subhan M, Qasim M, Ahmad R, Khan U (2003). Diallel analysis for estimating combining ability of quantitavely inherited traits in upland cotton. Asian J Plant Sci 2(11):853-857.

Tiwari A, Lal G (2004). Studies on heterosis for quantitative and qualitative characters in tomato (Lycopersicon esculentum Mill.). Progr Horti 36(1):122-127.

Weddle CL (1976). Petunias, 252-265 p. In: Mastaler L (Ed.). Bedding plants. Pennstate manual, State College.

Wijsman HJW, Jong JH (1985). On the interrelationships of certain species of Petunia IV. Hybridization between $P$. linearis and $P$. calycina and nomenclatorial on sequences in $P e$ tunia group. Acta Bot Neerl 34:337-349. 